University of Nebraska - Lincoln

DigitalCommons@University of Nebraska - Lincoln

Daugherty Water for Food Global Institute:

Faculty Publications

Daugherty Water for Food Global Institute

2020

\title{
Use of Multiple Environment Variety Trials Data to Simulate Maize Yields in the Ogallala Aquifer Region: A Two Model Approach
}

\author{
Vaishali Sharda \\ University of Nebraska-Lincoln, vsharda@ksu.edu \\ Mesfin Mekonnen \\ University of Nebraska-Lincoln, mmekonnen2@unl.edu \\ Chittaranjan Ray \\ University of Nebraska-Lincoln, cray@nebraska.edu \\ Prasanna H. Gowda \\ USDA-ARS Grazing Lands Research Laboratory, Prasanna.Gowda@usda.gov
}

Follow this and additional works at: https://digitalcommons.unl.edu/wffdocs

Part of the Environmental Health and Protection Commons, Environmental Monitoring Commons, Hydraulic Engineering Commons, Hydrology Commons, Natural Resource Economics Commons, Natural Resources and Conservation Commons, Natural Resources Management and Policy Commons, Sustainability Commons, and the Water Resource Management Commons

Sharda, Vaishali; Mekonnen, Mesfin; Ray, Chittaranjan; and Gowda, Prasanna H., "Use of Multiple Environment Variety Trials Data to Simulate Maize Yields in the Ogallala Aquifer Region: A Two Model Approach" (2020). Daugherty Water for Food Global Institute: Faculty Publications. 96.

https://digitalcommons.unl.edu/wffdocs/96

This Article is brought to you for free and open access by the Daugherty Water for Food Global Institute at DigitalCommons@University of Nebraska - Lincoln. It has been accepted for inclusion in Daugherty Water for Food Global Institute: Faculty Publications by an authorized administrator of DigitalCommons@University of Nebraska Lincoln. 

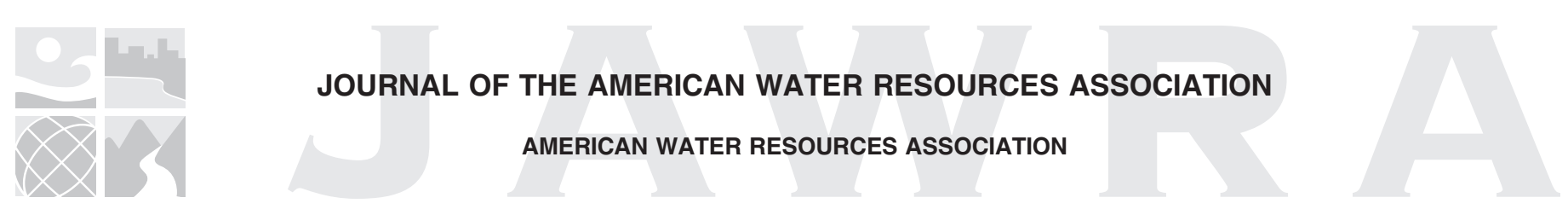

\title{
Use of Multiple Environment Variety Trials Data to Simulate Maize Yields in the Ogallala Aquifer Region: A Two Model Approach
}

\author{
Vaishali Sharda, Mesfin M. Mekonnen, Chittaranjan Ray, and Prasanna H. Gowda
}

\begin{abstract}
Research Impact Statement: DSSAT and AquaCrop models were calibrated using variety trial data to demonstrate their use for simulating maize production at regional scale when detailed in season crop growth data are not available.
\end{abstract}

ABSTRACT: With a long-term goal to optimize use of groundwater in the Ogallala Aquifer Region (OAR) to sustain food production systems, this study was conducted to calibrate Decision Support System for Agrotechnology Transfer (DSSAT) and AquaCrop crop modeling platforms to simulate maize production at a regional scale using historic datasets. Calibration of the models with local crop growth data and crop management practices is important, but usually this in-season crop growth information is not available. This study determined the possibility of using maize variety trial data for the evaluation of the CSM-Crop Estimation through Resources and Environmental Synthesis-Maize and AquaCrop models in the OAR. The models were calibrated and tested in three counties in Nebraska. Both the models were then used to simulate irrigated maize yield during 1988 to 2015 for all three counties. The criteria for evaluating the performance of these crop models included statistical parameters and graphical analysis. The performance of both models were then compared with the observed yield from field variety test results and historic National Agricultural Statistical Service yields. The results indicated that difference between yield of calibrated DSSAT model and observed yield was less than 10\% and AquaCrop root mean square error ranged from 740 to $1,820 \mathrm{~kg} / \mathrm{ha}$. Long-term comparison between observed and simulated Nebraska county yields also indicated confidence in calibrating crop models with typical end of season yield data and using these models for studying crop production at regional scales when detailed in-season crop growth observed data are not available.

(KEYWORDS: crop simulation; DSSAT; AquaCrop; cultivar coefficients; calibration; long term.)

\section{INTRODUCTION}

As the population of the world soars, the agricultural production and scientific communities are faced with the challenge of increasing food production and adapting the agricultural systems to changing climate while sustaining the environment. Policy makers and researchers need more accurate prediction of food production at large spatial scales (Huang et al. 2017). Several crop models like Decision Support System for Agrotechnology Transfer (DSSAT), (Jones et al. 2003); EPIC, (Williams et al. 1989); AquaCrop, (Vanuytrecht et al. 2014); SALUS, (Basso et al. 2006); APSIM, (Keating et al. 2003), etc. have been around for several decades. These models are tools that incorporate several guiding principles and methods of crop physiology, agronomy, agro meteorology,

Paper No. JAWR-18-0112-P of the Journal of the American Water Resources Association (JAWR). Received August 1, 2018; accepted July 21, 2020. (C) 2020 American Water Resources Association. Discussions are open until six months from issue publication.

Nebraska Water Center (Sharda, Ray), University of Nebraska Lincoln, Nebraska, USA; Robert B. Daugherty Water for Food Global Institute (Mekonnen), University of Nebraska Lincoln, Nebraska, USA; and USDA-ARS Grazing Lands Research Laboratory (Gowda), El Reno, Oklahoma, USA (Correspondence to Sharda: vsharda@ksu.edu).

Citation: Sharda V., M.M. Mekonnen, C. Ray, and P.H. Gowda. 2020. "Use of Multiple Environment Variety Trials Data to Simulate Maize Yields in the Ogallala Aquifer Region: A Two Model Approach." Journal of the American Water Resources Association 1-15. https://oi. org/10.1111/1752-1688.12873. 
soil mechanics, soil water, and economics, among others (Hoogenboom 2000); and have been extensively used to analyze and evaluate the impacts of climate change and environmental factors on crop production systems (Rosenzweig and Iglesias 1998; Hermans et al. 2010; Nelson et al. 2010; Semenov and Shewry 2011).

Several studies have used crop models in conjunction with climate projections of Global Climate Models around the world (Basak et al. 2010; Dias et al. 2016) and in the United States (U.S.) (Rao 2002). The analyses have included yield risk assessment (Challinor et al. 2018); impact of change in temperature and precipitation changes in yields (Alexandrov and Hoogenboom 2000); economic analyses (Nelson et al. 2014) among others. During the course of conducting research and reporting results of the studies mentioned earlier, scientists have evaluated different crop management strategies like planting dates, fertilizer, and irrigation applications as well as selecting cultivars or hybrids that might help to mitigate the impact of climate change on agricultural production systems.

The process of adjusting cultivar specific parameters so that simulated values mimic the observed field data is called calibration (Hoogenboom et al. 2015). Crop models, when locally calibrated and validated, can be effectively used as decision support tools in different environments (Kisekka et al. 2016). These models rely on detailed in-season crop growth and end of season yield data over several crop production cycles to effectively calibrate the models. To apply a model to a new location, or use it with new varieties, it is important to calibrate and evaluate it extensively (Bao et al. 2017). Given the personnel cost associated with data collection, these data are costly to obtain and hence are not readily collected during field experiments. The scarcity or even absence of these data is a serious limitation to use of tools like crop models to study crop productivity, productivity gaps, and understand why these gaps exist (Burke and Lobell 2017). In most of the studies conducted, the crop cultivars are generally chosen from the default values provided with the crop model or obtained from literature. This overlooking of the calibration and evaluation procedures introduces additional errors and noise in the model simulations. Therefore, selection of cultivars and crop hybrids for climate change studies remains a challenge. Improper calibration of the crop model or failure to validate the model over a temporal scale could result in uncertainties and errors in the simulations effecting the output of impact studies.

All models are considered imperfect representations of complicated, real-world biological processes, with their precision restricted by their design and structure (Watson and Challinor 2013; Huang et al. 2017). Calibration procedures have been developed for several crops like maize, soybean, winter wheat, grain sorghum, etc., when limited experimental data are available (Soler et al. 2007; Gaiser et al. 2010). New and improved cultivars and hybrids are continuously developed, but these are not updated or parameterized regularly in the crop models (Holzworth et al. 2015). Due to inherent differences between the working of different models, there have been discussions on the uncertainties that crop models could introduce in environmental impact studies (Rötter et al. 2012). In spite of the model improvements, structural ambiguity remains an unavoidable concern for model simulations. The use of multimodel ensembles (Rosenzweig et al. 2013) to minimize uncertainties are becoming an accepted approach to improve forecast by correcting different biases and making use of strengths of individual models (Gupta et al. 2012). Martre et al. (2015) compared several crop models with an ensemble of their results and found that multimodel forecasts were more precise than their individual runs. Several other studies have also indicated that use of multiple models vs. individual models offer more robust information (Iocola et al. 2017; Yin et al. 2017).

Rötter et al. (2012), Bassu et al. (2014), and Asseng et al. (2013) have compared multiple models for barley, maize, and wheat, respectively. However, comparison of multiple models at a regional scale for crops like maize and soybean remains to be seen when detailed experimental data are not available to calibrate the model. Also, a gap exists in reporting of data about calibration in crop modeling studies at a regional scale when using experimental data (Grassini et al. 2015a, b). One approach under this scenario could be to use multiyear crop variety trial data from different locations. Crop variety trials are aimed at evaluation of improved varieties or hybrids of crops using the data generated by multienvironmental trials (MET) (Smith et al. 2001; Smith et al. 2005). Bao et al. (2017) studied the feasibility of using maize variety trial data for evaluation and comparison of DSSAT and EPIC models in the state of Georgia, U.S. We selected DSSAT and AquaCrop models to study and compare the performance of these two models in simulating yields of maize in the Northern High Plains (NHP) region of the Ogallala aquifer. DSSAT and AquaCrop are two of the most commonly and widely used crop models around the region as well as around the world. These two models were intentionally chosen so as to compare the performance of a detailed, process-based crop model (DSSAT) and a simpler model (AquaCrop) for field variety trials for maize in NHP when detailed crop phenological data are unavailable.

The DSSAT (Jones et al. 2003; Hoogenboom et al. 2015) has been extensively used (Tsuji et al. 1998; 
Thorp et al. 2008) for assessing agricultural management options. DSSAT version 4.7 comprises models for more than 28 crops that simulate crop growth, development, and yield along with management strategies that involve irrigation, fertilizer application, crop rotations, and others (Sharda et al. 2017). DSSAT is used to simulate crop water use and production along with the evaluation of management strategies under different environmental conditions (Liu et al. 2011; Soler et al. 2011; McNider et al. 2015). DSSAT has also been employed at various temporal and spatial scales to model climate change impacts on crop production (Tubiello et al. 2002; Carbone et al. 2003) and to forecast yield (Bannayan et al. 2003; Soler et al. 2007). DSSAT's Crop Estimation through Resources and Environmental Synthesis (CERES) Maize (Ritchie et al. 1998) calculates crop growth and simulates water and nitrogen balance at a daily time step by simulating processes of soil water, nutrient, and plant growth, along with developmental processes for the formation of final crop yield and yield components. The model simulates six phenological stages for a maize plant. Each phenological stage is controlled by environmental factors such as water, sunlight, atmospheric gases, etc., in addition to weather factors and plant genetics.

The AquaCrop model was developed by the Food and Agricultural Organization (FAO) and evolves from the concepts of yield response to crop water use originally presented in the FAO Irrigation and Drainage Paper No. 33 (Doorenbos and Kassam 1979) to a concept of a normalized crop water productivity (Steduto et al. 2009). The model separates the nonproductive soil evaporation from productive crop transpiration and simulates crop biomass of herbaceous crops directly from actual crop transpiration through a normalized water productivity parameter under different biophysical and management conditions (Raes et al. 2009; Steduto et al. 2009; Steduto et al. 2012). The model maintains an optimal balance between accuracy, robustness, and simplicity, by requiring a relatively small number of model input parameters but ensuring realistic simulation of crop responses to environment through fundamental and often complex biophysical processes. The AquaCrop model has been validated and applied successfully for several crops under different environmental and agronomic settings (Hsiao et al. 2009; Todorovic et al. 2009; Araya and Stroosnijder 2010; Araya et al. 2010a, b; Stricevic et al. 2011; Abedinpour et al. 2012; Vanuytrecht et al. 2014).

In the absence of detailed in-season experimental crop growth data, this study was undertaken to explore the feasibility of using multienvironment maize variety trial data for the evaluation of two structurally different crop simulation models. Two specific objectives of this study were to calibrate DSSAT and AquaCrop models using multiple year and multiple location maize variety trial data; and to use the calibrated models in simulating long-term historic yields and compare them with observed yields to conclude whether the performance of the two assessed models is comparable in predicting maize yield in NHP.

\section{METHODOLOGY}

\section{Data}

University of Nebraska, Lincoln Extension's CropWatch portal provides information on the institute's variety testing program. Extensive hybrid and variety trials for maize, soybean and other crops are conducted at various locations spread throughout the state to help the producers, extension personnel, and researchers identify the best performing varieties/hybrids according to their needs. For this study, yield data from maize variety trials conducted from 2009 to 2015 were used (Regassa et al. 2009, 2010, 2011, 2012, 2013; Regassa and Shapiro 2014, 2015). Three maize hybrids were selected for modeling, based on the criterion that the varieties were grown in all three counties from 2009 until 2015. Maize cultivars selected were Pioneer 33D49, Nutech/G2Genetics G5H513, and Nutech/G2Genetics G5X411. The locations selected were Clay, Phelps and Lincoln counties in Nebraska (Figure 1). The locations were selected based on availability of continuous weather data for the location where the variety trials were conducted. Irrigated trials designed to have no water stress and pest and disease damage were selected.

The input data required to run the crop models include daily air temperatures (maximum and minimum), precipitation, and solar radiation, along with soil properties, management information (e.g., date of planting, row spacing, and plant population), and hybrid-specific genetic coefficients that are required by the models to simulate yield (Sharda et al. 2017). Observed climate data for all the counties were obtained from University of Nebraska High Plains Regional Climate Center's Automated Weather Data Network (AWDN 2018). Twenty-eight years (19882015) of climate data from three weather stations located near the variety trial sites were downloaded. The soil types varied with year for some of the variety trials (in which fields within a county were different among some years) but for this analysis the most common soil type was used for each location. The soil type was Crete silt loam for Clay, Holdrege silt loam 


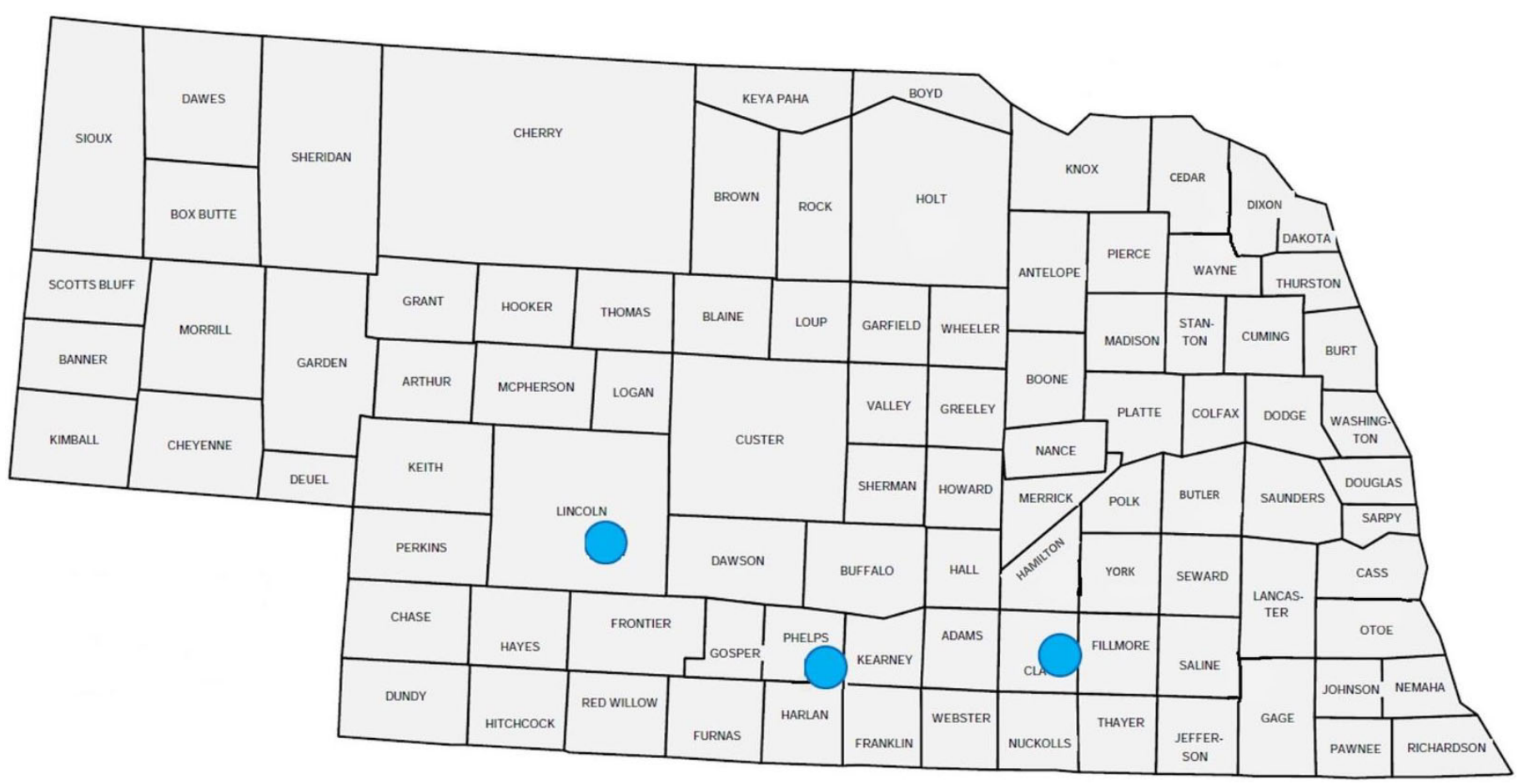

FIGURE 1. Irrigated maize variety trial sites selected for this study: Clay, Phelps, and Lincoln Counties in Nebraska (Adapted from Regassa et al., 2012).

for Phelps, and Cozad silt loam for Lincoln. The Natural Resource Conservation Service National Cooperative Soil Survey (NCSS 2013) Soil Survey Geographic database that provides soil data for more than $95 \%$ of the counties of the conterminous U.S., was used to download the soil profiles for study sites. The soils data were then converted to DSSAT soil profile using the methodology given in Sharda et al. (2017). National Agricultural Statistical Service (USDA NASS 2018) historic county yield data were used to compare simulated maize yields with observed county averages.

In DSSAT crop management details such as planting dates, plant population, row spacing, and fertilizer type and amount were set to what was reported in irrigated variety trial reports. The plant population was set to 6 plants $/ \mathrm{m}^{2}$, row spacing of $30 \mathrm{~cm}$ and planting depth of $7 \mathrm{~cm}$ was used. Irrigation amounts and dates are not specified in the variety trials, therefore, irrigation in the model was set to no water stress or "irrigate when needed" setting. Under this setting, DSSAT attempts to minimize water stress throughout the growing season by applying irrigation based on soil water content (McNider et al. 2015). Similarly, for AquaCrop crop planting, harvesting date and plant density as reported in crop variety trial reports was used. The plant population was set to 6 plants $/ \mathrm{m}^{2}$ at a row spacing of $30 \mathrm{~cm}$.

\section{Model Calibration}

DSSAT. Yield and phenology in CERES-Maize are determined by six genetic coefficients, and the purpose of calibration is to obtain reasonable estimates of these coefficients by comparing simulated yield data with observed data. These genetic coefficients are thermal time from seedling emergence to the end of the juvenile phase (P1), extent to which development is delayed for each hour increase in photoperiod above the longest photoperiod at which development proceeds at a maximum rate (P2), thermal time from silking to physiological maturity (P5), maximum possible number of kernels per plant (G2), kernel filling rate during the linear grain filling state and under optimum conditions (G3), and the interval in thermal time (degree days) between successive leaf tip appearances (PHINT) (Table 1).

The first step of calibration included adjusting Soil Fertility Factor (SLPF) as it is one of the most important factors that impact simulated yield (total biomass) (Guerra et al. 2008) and is accredited with impacting soil fertility and soil-based pests (Bao et al. 2017). Due to lack of observations of biomass, SLPF was manually adjusted to minimize root mean square error (RMSE) between observed and initial simulated yield. Adjustment of SLPF was followed by use of GENCALC (Hunt et al. 1993) to calibrate the genetic 
Use of Multiple Environment Variety Trials Data to Simulate Maize Yields in the Ogallala Aquifer Region: A Two Model Approach

TABLE 1. Cultivar coefficients for the Crop Estimation through Resources and Environmental Synthesis (CERES)-Maize model.

\begin{tabular}{|c|c|c|c|c|}
\hline Coefficient & Definition & Units & Min. & Max. \\
\hline $\mathrm{P} 1$ & Thermal time from seedling emergence to end of juvenile phase & ${ }^{\circ} \mathrm{C}$ days & 110 & 458 \\
\hline $\mathrm{P} 2$ & $\begin{array}{l}\text { Extent to which development is delayed for each } \\
\text { hour increase in photoperiod above the longest } \\
\text { photoperiod at which development proceeds at a maximum rate }\end{array}$ & day $/ \mathrm{h}$ & 0 & 3 \\
\hline P5 & Thermal time from silking to physiological maturity & ${ }^{\circ} \mathrm{C}$ days & 390 & 1,000 \\
\hline G2 & Maximum possible number of kernels per plant & kernel/plant & 248 & 990 \\
\hline G3 & $\begin{array}{l}\text { Kernel filling rate during the linear grain filling } \\
\text { state and under optimum conditions }\end{array}$ & $\mathrm{mg} / \mathrm{day}$ & 4.4 & 16.5 \\
\hline PHINT & Interval in thermal time between successive leaf tip appearances & ${ }^{\circ} \mathrm{C}$ days & 30 & 75 \\
\hline
\end{tabular}

coefficients. GENCALC uses genetic coefficients of the default cultivar selected and iterates to a best value of the coefficient by lowering the RMSE between observed and simulated variables. Since only observed yield was available for calibration, the rule for calibration in GENCALC was set to only yield. Using this rule, the genetic coefficients G2 and G3 were automatically calibrated using GENCALC. Remaining cultivar coefficients P1, P2, P5, and PHINT were manually adjusted to further diminish the difference between observed and simulated yields. The cultivars Pioneer 3394, H512, and 2600-2650 GDD, available in DSSAT databases were used as base cultivars to calibrate the cultivars Pioneer 33D49, Nutech/G2Genetics G5H513, and Nutech/ G2Genetics G5X411, respectively.

AquaCrop. In AquaCrop, crop biomass is directly related to crop transpiration, which is directly influenced by the canopy cover (CC). Therefore, calibration of AquaCrop was done by adjusting the crop parameters to determine the development of CC. The canopy growth coefficient, canopy decline coefficient, maximum CC, days to emergence, days to senescence, and days to full maturity are the main parameters that determine the development of CC (Steduto et al. 2009). These parameters were iteratively adjusted until the RMSE between the simulated yields and field level measured yields are minimized.

\section{Maize Yield Simulation}

Following calibration and statistical evaluation, both DSSAT and AquaCrop models were used to simulate yield under irrigated conditions for Clay, Lincoln, and Phelps counties using long-term historical weather data from 1988 to 2015. The simulated results from both the models were analyzed to assess the differences between end of season yield simulations between the two models for different environments, but using the same crop management as was used in the variety trial data. The methods used in
DSSAT to simulate various processes in the model include the FAO 56 (Allen et al. 1998) and the Suleiman-Ritchie (Suleiman and Ritchie 2003) options for estimating reference evapotranspiration and soil evaporation, respectively, and the Soil Conservation Service option for estimating infiltration. The simulated yields averaged over the cultivars for each location were compared with NASS (USDA NASS 2018) historic county averages.

\section{Statistical Analysis}

Statistical criteria commonly used for evaluating crop models (Anothai et al. 2008; Bao et al. 2017) were selected for this study. These include RMSE and index of agreement $(d)$ or $d$-stat (Willmott et al. 2012), given by Equations (1 and 2), respectively:

$$
\begin{array}{r}
\operatorname{RMSE}=\sqrt{\frac{\sum_{i=1}^{n}\left(P_{i}-O_{i}\right)^{2}}{n},} \\
d=1-\left[\frac{\sum_{i=1}^{n}\left(P_{i}-O_{i}\right)^{2}}{\sum_{i=1}^{n}\left(\left|P_{i}^{\prime}\right|+\left|O_{i}^{\prime}\right|\right)^{2}}\right],
\end{array}
$$

where $n$ is the number of observations, $P_{i}$ is the simulated value for the $i$ th measurement, $O_{i}$ is the observed value for the $i$ th measurement, and $P_{i}^{\prime}=P_{i}-\bar{O}$ and $O_{i}^{\prime}=O_{i}-\bar{O}$, where $\bar{O}$ is the mean of all observations. " $d$ " measures the relative erroring model estimates and indicates the degree to which simulated and observed values show similar variation from the observed averages (Zeleke et al. 2011). The closer the value of $d$-stat is to 1 , the better the simulation with a value of 0 indicating complete disagreement (Greaves and Wang 2016). The smaller the RMSE value is, the better the simulation fit. The calibrated values for the three maize cultivars were copied into DSSAT cultivar (CUL) file to further simulate maize yields and evaluate the results. 


\section{RESULTS AND DISCUSSION}

\section{Model Calibration}

As the first step of cultivar calibration in DSSAT, the soil fertility factor, SLPF were determined to be 0.9, 0.82, and 0.75 for Clay, Lincoln, and Phelps counties, respectively (Table 2). Values of observed and simulated yields averaged over the cultivars along with RMSE and d stat for calibrated SLPF values are given in Table 2. The average percentage difference between observed and simulated yields was $<7 \%$ in all the counties. RMSE value was the lowest for Clay county $(1,388 \mathrm{~kg} / \mathrm{ha})$, whereas it was approximately $1,865 \mathrm{~kg} / \mathrm{ha}$ for both Lincoln and Phelps county. Phelps County had the lowest average $d$-stat value of 0.29 among the three counties. Low value of $d$-stat in Phelps County can be attributed to the fact that $d$-stat is overly sensitive to extreme values due to the squared differences and any large deviations in values can strongly influence it (Yang et al. 2014). RMSE values for Phelps County are comparable to both Clay and Lincoln Counties.

The calibration of cultivars Pioneer 3394, H512, and 2600-2650 GDD based on cultivars Pioneer 33D49, Nutech/G2Genetics G5H513, and Nutech/ G2Genetics G5X411, respectively, involved calibrating growth and phenology coefficients. The values of the cultivar coefficients are given in Table 3. These values of GENCALC calibrated coefficients G2 and G3 ranged from 526 to 903 kernel/plant and 9 to $15.5 \mathrm{mg} /$ day, respectively. The calibrated values of G3 were higher than the base cultivars in case of all three cultivars indicating a higher grain filling rate for Pioneer 33D49, Nutech/G2Genetics G5H513, and Nutech/G2Genetics G5X411 as compared to the base cultivars selected for calibration. The higher value of G3 for G5X411 among the calibrated cultivars indicated that it is a higher yielding cultivar as compared to the other two. The values for other cultivar coefficients that were manually adjusted to match observed yields include $\mathrm{P} 1$, that ranged from $185^{\circ} \mathrm{C}$ to $237^{\circ} \mathrm{C}$ days; $\mathrm{P} 2$ from 0.3 to 0.75 day/h; P5,

TABLE 2. Soil fertility factor (SLPF) for three counties and observed (Obs.) and simulated (Sim.) maize yield. Statistics include root mean square error (RMSE); and index of agreement ( $d$-stat) between simulated and observed yield.

\begin{tabular}{lccccc}
\hline Location & SLPF & $\begin{array}{c}\text { Obs. yield } \\
(\mathbf{k g} / \mathbf{h a})\end{array}$ & $\begin{array}{c}\text { Sim. yield } \\
(\mathbf{k g} / \mathbf{h a})\end{array}$ & $\mathbf{R M S E}$ & $\boldsymbol{d}$-stat \\
\hline Clay & 0.9 & 16,250 & 15,299 & 1,388 & 0.78 \\
Lincoln & 0.82 & 14,451 & 14,573 & 1,865 & 0.68 \\
Phelps & 0.75 & 15,484 & 14,794 & 1,863 & 0.29 \\
\hline
\end{tabular}

TABLE 3. Calibrated values of cultivar coefficients for Pioneer 33D49, Nutech/G2Genetics G5H513, and Nutech/G2Genetics G5X411for Decision Support System for Agrotechnology Transfer (DSSAT) and AquaCrop.

\begin{tabular}{|c|c|c|c|}
\hline Parameter & $\begin{array}{l}\text { Pioneer } \\
\text { 33D49 }\end{array}$ & G25H513 & G25X411 \\
\hline \multicolumn{4}{|l|}{ DSSAT, CERES-Maize } \\
\hline P1 & 236.8 & 185.0 & 215.0 \\
\hline $\mathrm{P} 2$ & 0.31 & 0.75 & 0.35 \\
\hline P5 & 878 & 850.0 & 875.0 \\
\hline G2 & 840 & 902.9 & 526.1 \\
\hline G3 & 9.25 & 12.58 & 15.40 \\
\hline PHINT & 42.88 & 49.0 & 40.00 \\
\hline \multicolumn{4}{|l|}{ AquaCrop } \\
\hline $\begin{array}{l}\text { Canopy growth } \\
\text { coefficient }(\% / \text { day })\end{array}$ & 14.5 & 15.2 & 14.5 \\
\hline $\begin{array}{l}\text { Maximum canopy } \\
\text { cover }(\mathrm{CCx}, \%)\end{array}$ & 95 & 99 & 95 \\
\hline $\begin{array}{l}\text { Canopy decline } \\
\text { coefficient }(\% / \text { day })\end{array}$ & 9.0 & 7.4 & 8.7 \\
\hline $\begin{array}{l}\text { Upper threshold } \\
\text { for stomatal closure }\end{array}$ & 0.65 & 0.69 & 0.69 \\
\hline
\end{tabular}

from $850^{\circ} \mathrm{C}$ to $878^{\circ} \mathrm{C}$ days; and PHINT, that varied between $40^{\circ} \mathrm{C}$ and $49^{\circ} \mathrm{C}$ days. In case of Nutech/ G2Genetics G5H513, the value of PHINT was same as that of the base cultivar selected for calibration.

AquaCrop was also satisfactorily calibrated and validated in this study. During calibration, parameters were adjusted until they provided a better index of agreement and lower RMSE values. The calibrated values of AquaCrop adjusted parameters are given in Table 3. For other parameters, we have adopted the standard AquaCrop values for maize.

The maize yield simulated by DSSAT CERESMaize during calibration period strongly agreed with the observed values (Table 4). A comparison of simulated and observed yields for each county and cultivar combination with the lowest RMSE are shown in Figure 2. For Lincoln County, different cultivars had the lowest RMSEs for DSSAT and Aquacrop so two datasets are presented in Figure 2c, DSSAT - G25H513 and Aquacrop - Pioneer 33D49. The lowest RMSE during calibration was $920 \mathrm{~kg} / \mathrm{ha}$ in Clay county for the Cultivar G25X411, 1,305 kg/ha in Clay county for Pioneer 33D49, and 1,315 kg/ha in Lincoln county for G25H513. The deviation of the simulated yield from observed yield for maize ranged between $<1 \%$ and $7 \%$. It is important to note that the performance of DSSAT varied between locations and among cultivars. For most of the simulations, the model overestimate yield, which is expected since the model does not consider limitations like pests, weeds, etc. During certain years (e.g., 2014), maize yield was underestimated, but since the deviation of yield was in the range of less than $10 \%$, it was not considered to be 
an issue with the calibration of the model (Bao et al. 2017; Araya et al. 2017a, b, c).

The $d$-stat mostly ranged between 0.6 and 0.9 indicating that the model simulated the observed values adequately during calibration. Overall, the statistical evaluation of the model indicated that simulated the maize yield satisfactorily. There have been several studies in the past in the NHP region where crop simulation models have been found to satisfactorily simulate grain yield for different environments (Saseendran et al. 2013; Liu et al. 2015; Araya et al. 2017a, b, c). To summarize, DSSAT simulated maize yield for the dataset evaluated demonstrated a fair agreement with observed yield and was comparable to the calibration dataset.

AquaCrop simulated maize yield well during the calibration period with RMSE ranging from 740 to $1,820 \mathrm{~kg} / \mathrm{ha}$ between cultivars and locations. The relationship between the measured and simulated yield was fair. Index of agreement obtained was comparatively lower as compared to some of the other similar simulations carried out in the region (Araya et al. 2017a, b, c) and other places (Heng et al. 2009; Hsiao et al. 2009).

Performances indices of DSSAT were better than AquaCrop for most of the location and cultivar combinations. This was expected due to simplification of complex processes in AquaCrop (Araya et al. $2017 \mathrm{a}, \mathrm{b}$, c) as compared to DSSAT. The performance of AquaCrop during calibration period was better in Phelps county for cultivar G25X411 where the index of agreement and RMSE for AquaCrop were 0.6 and $740 \mathrm{~kg} / \mathrm{ha}$, respectively, as compared to 0.2 and $1,216 \mathrm{~kg} / \mathrm{ha}$ in case of DSSAT. However, there is overestimation and underestimation in some counties for all the cultivars calibrated. When compared with observed yields, the percentage difference between Aquacrop simulated yields ranged between $0.6 \%$ and $11 \%$ among locations and hybrids.

\section{Maize Yield Simulation}

Comparison of long-term historic DSSAT yield simulations with NASS yields (years 1988-2015) averaged over cultivars for all the locations are given in Figure 3a. The model was able to capture the yield variability over the time of simulation, which is most likely attributed to environmental factors. It was found that the difference between simulated and measured yield was higher in the early 1990s and the simulated and observed maize yields converged in the year 2001 onwards. This trend is expected since the present day cultivars are improved, high yielding varieties as compare to the cultivars that existed nearly 30 years ago (Richards 2006; Grassini et al. 2015a, b; Qian and Zhao 2017). The crop management factors remained same over the simulation period and actual historic weather data were used, so the yield variation in Figure 3 could be the explained by the use of genetically improved cultivars (e.g. drought tolerant hybrids) as well as variation in crop management practices over time. Some of the other factors not considered in this study that could attribute to the yield difference between observations and simulations could include factors like introduction of conservation tillage as well as transgenic pest control (Edgerton 2009). Since irrigated yields remove the impact of rainfall variability on yield (Bao et al. 2017 ), this variation in yield indicates that environmental conditions and weather play a significant role in the yield variability from year to year and from one location to another. For AquaCrop (Figure 3b), the simulated yield follows a similar trend of converging to NASS observed yields year 2000 onward. In contrast to DSSAT simulations, these simulated yields, however, show smaller variability over time and remain in the same range from 1988 to 2015 .

The variation in simulated maize yield for 28 years (1988-2015) for both models at each location are presented in Figure 4. The average simulated yields for

TABLE 4. The average simulated maize yield for DSSAT and AquaCrop calibration of the three cultivars. Statistics include index of agreement $(d)$; and RMSE of simulated and observed yield.

\begin{tabular}{|c|c|c|c|c|c|c|c|c|c|}
\hline \multirow[b]{2}{*}{ County } & \multicolumn{3}{|c|}{ Pioneer 33D49 } & \multicolumn{3}{|c|}{ G25H513 } & \multicolumn{3}{|c|}{ G25X411 } \\
\hline & Yield, kg/ha & $d$ & RMSE & Yield, kg/ha & $d$ & RMSE & Yield, kg/ha & $d$ & RMSE \\
\hline \multicolumn{10}{|l|}{ DSSAT } \\
\hline Clay & 15,472 & 0.7 & 1,305 & 16,601 & 0.7 & 1,939 & 16,270 & 0.9 & 920 \\
\hline Lincoln & 14,850 & 0.6 & 2,865 & 14,892 & 0.7 & 1,315 & 16,233 & 0.6 & 1,414 \\
\hline Phelps & 15,186 & 0.2 & 2,557 & 16,088 & 0.4 & 1,816 & 16,291 & 0.2 & 1,216 \\
\hline \multicolumn{10}{|l|}{ AquaCrop } \\
\hline Clay & 14,941 & 0.5 & 1,323 & 16,360 & 0.6 & 1,481 & 16,165 & 0.8 & 1,216 \\
\hline Lincoln & 13,752 & 0.3 & 1,606 & 13,752 & 0.4 & 1,887 & 14,547 & 0.5 & 1,821 \\
\hline Phelps & 13,709 & 0.3 & 1,726 & 16,014 & 0.3 & 2,064 & 14,781 & 0.6 & 740 \\
\hline
\end{tabular}


Sharda, Mekonnen, Ray, and Gowda
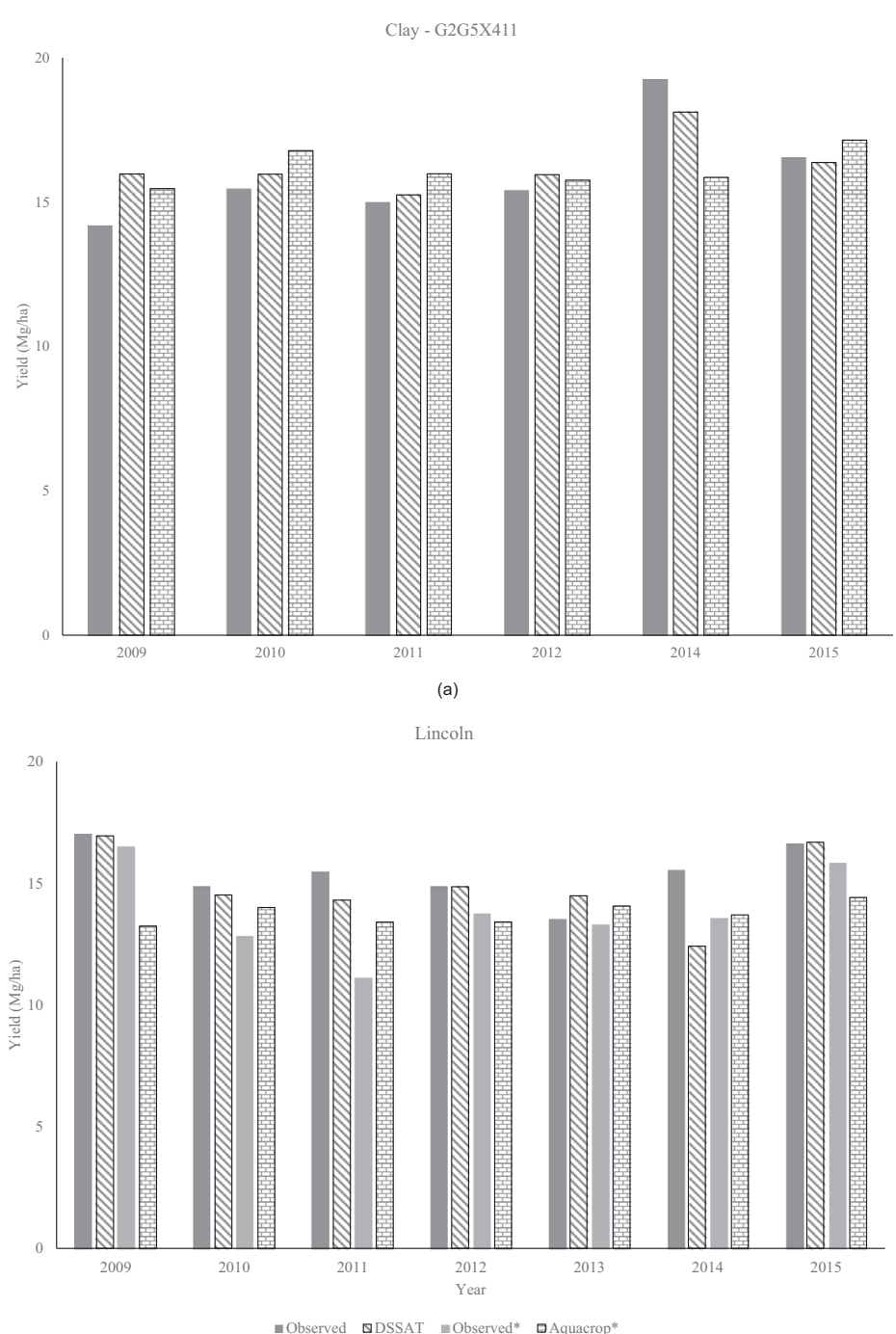

(b)

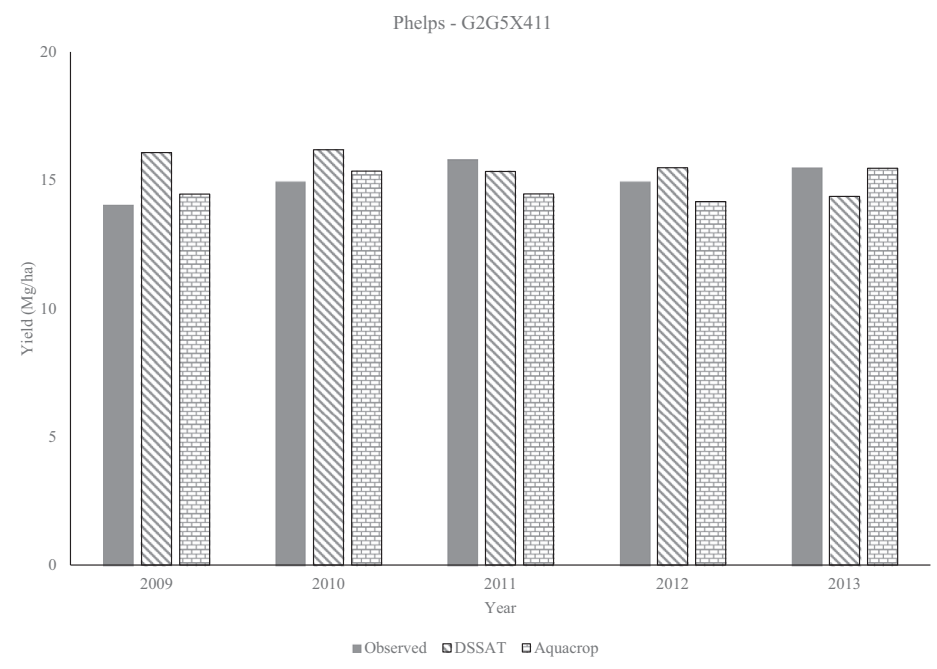

(c)

FIGURE 2. A comparison of observed yields with DSSAT and Aquacrop simulated yields for different cultivar and locations (a) Clay County (b) Lincoln County and (c) Phelps County. *For Lincoln County, different cultivars had the lowest RMSEs for DSSAT and Aquacrop so two datasets are presented in this figure, DSSAT - G25H513 and Aquacrop - Pioneer 33D49. 

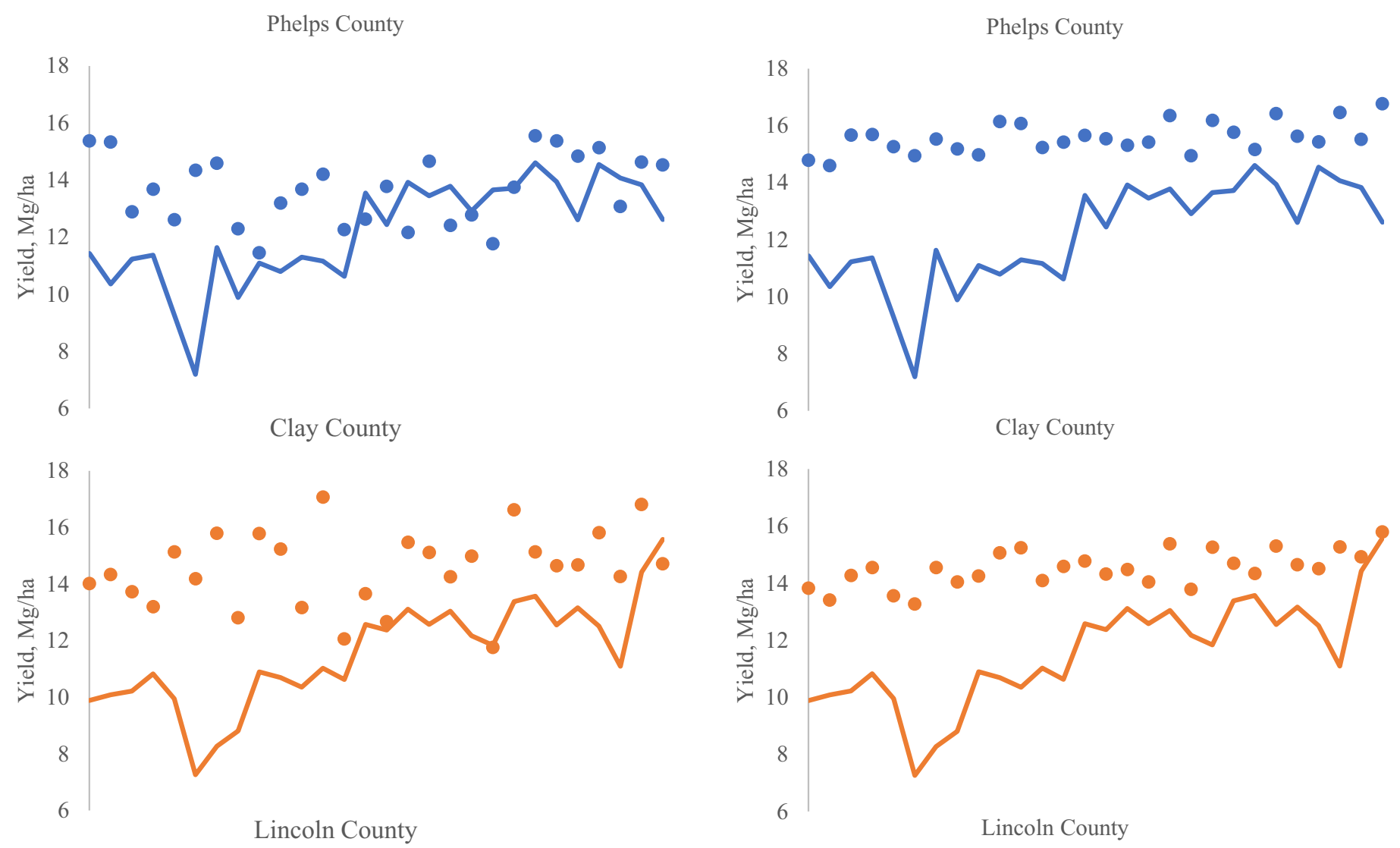

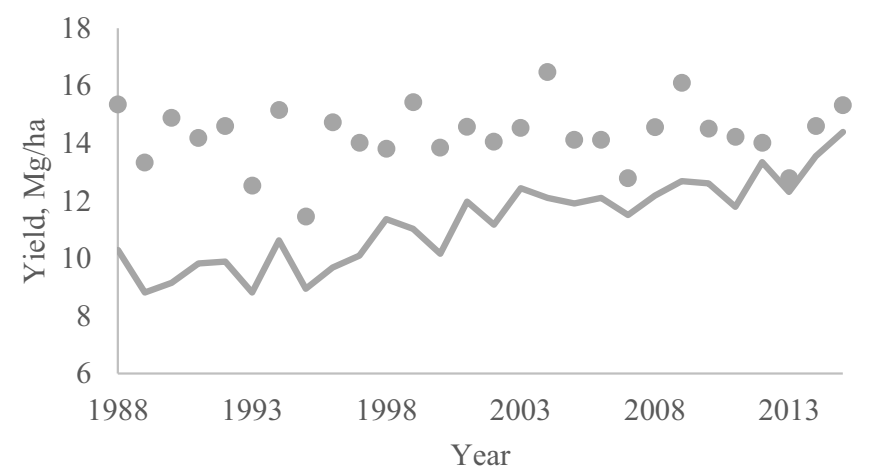

(a)

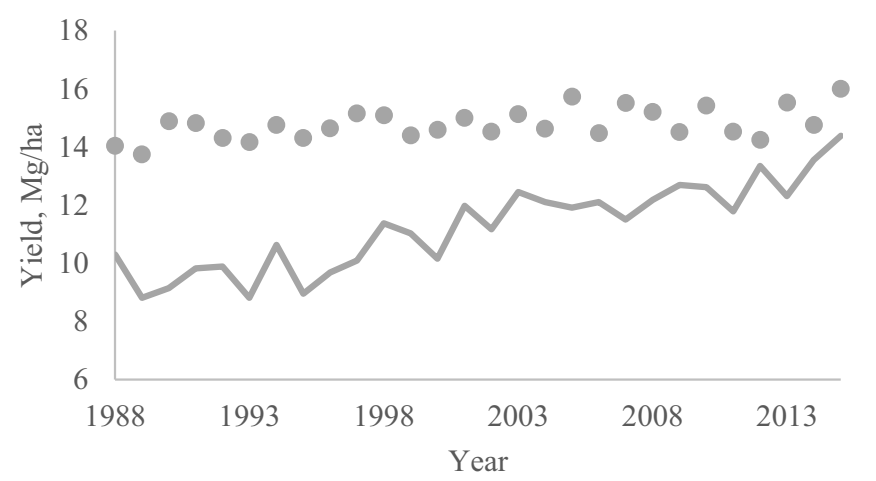

(b)

FIGURE 3. Comparison of observed historic National Agricultural Statistical Service (NASS) County yields for years 1988-2015 with simulated DSSAT (a) and AquaCrop (b) yields. Lines represent observed NASS yields and dots represent simulated yields. Simulated yields are averaged over the cultivars.

DSSAT ranged from 11.4 to $17 \mathrm{Mg} /$ ha with a median yield of $14.25 \mathrm{Mg} / \mathrm{ha}$ at the three locations. DSSAT yields from Phelps County had the most variation and Lincoln County had the least. Simulations of AquaCrop were similar to DSSAT in Lincoln County with maximum yield about $50 \mathrm{~kg} / \mathrm{ha}$ more than DSSAT. AquaCrop, overall, had less variability than DSSAT simulations, which is also evident from the time series analysis of averaged yields (Figure 3). The minimum yields simulated with AquaCrop were higher than DSSAT simulated yields in both Clay and Phelps counties. AquaCrop yields ranged from about 13.5 to $16.65 \mathrm{Mg} /$ ha over the three locations. Simulated yields averaged over year 2000 onwards (2000-2015) and three different cultivars indicate that both DSSAT and AquaCrop overestimated yields at all three locations (Figure 5) as compared to observed county yields with the difference between simulated and observed yield ranging from $0.3 \%$ to $19 \%$. DSSAT yields were found to be closer to be observed yields as compared to AquaCrop yields at all locations with the variation in $<0.3 \%$ to $12 \%$. This 


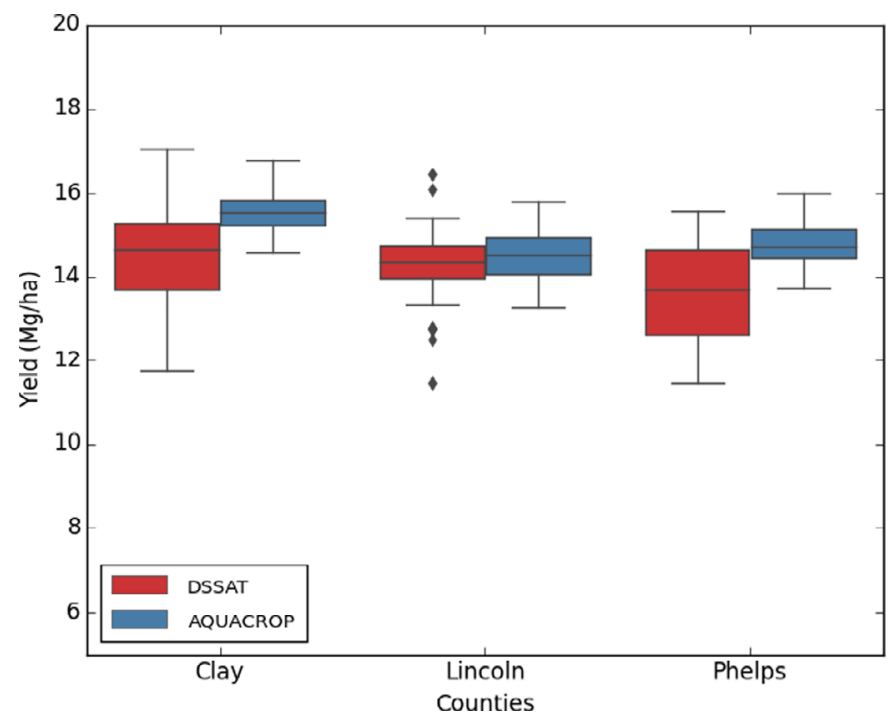

FIGURE 4. Variation in simulated maize yields by DSSAT and AquaCrop models.

overestimation, although high, is close to the calibration period $(0.6 \%-11 \%)$ and is in agreement with several studies that have adopted similar approach for calibrating the models (Klein et al. 2012; Bao et al. 2017; Adnan et al. 2019) There are several factors that are not accounted for in the models used and could have attributed toward the overestimation of crop yield. These factors include, but are not limited to, several biotic and abiotic stresses (Garibay et al. 2019) as well as pedo-climatic conditions (Brilli et al. 2017).

\section{SUMMARY AND CONCLUSIONS}

Before crop models can be used as tools to help in agricultural management decision making, they need to be tested extensively at regional levels (Asseng et al. 2013). This process of calibrating different cultivar coefficients is important to establish confidence in model simulations. However, many times detailed inseason crop growth data are unavailable to be used in the calibration process. This study was designed to demonstrate the use of regional variety trial data from various locations in Nebraska to calibrate DSSAT and AquaCrop crop models for maize in absence of in-season crop growth data. The variety trials data used in this study were obtained entirely from a public source, so that this approach and methodology could be easily reconducted in other regions.

Both DSSAT (CERES-Maize) and AquaCrop models were calibrated for three popular cultivars grown

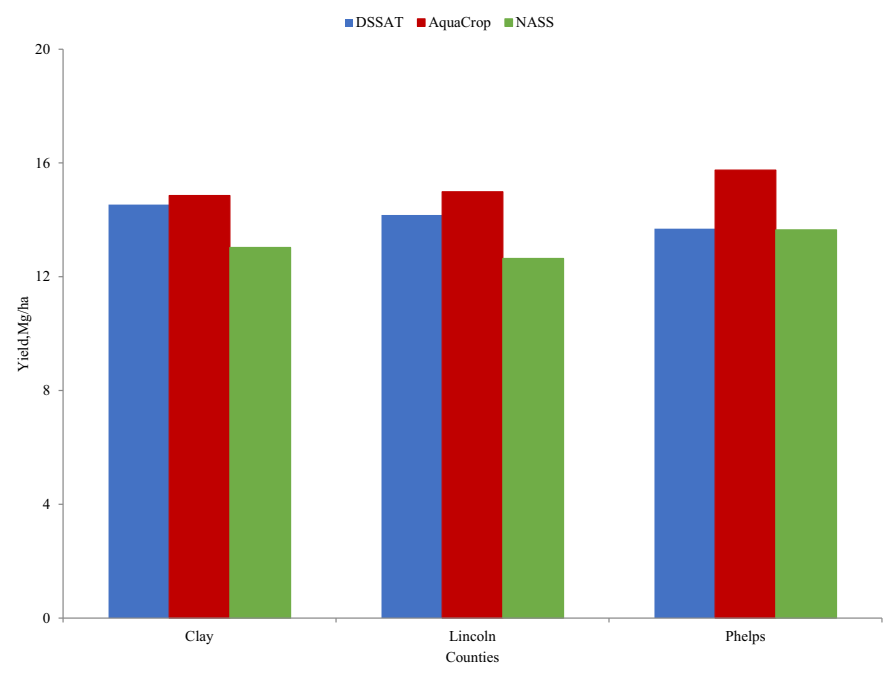

FIGURE 5. Comparison of simulated yield averaged over 16 years (2000-2015) and cultivars (P33D49, G25H513, G25X411) with observed NASS county yields at all the three locations studied in Nebraska for DSSAT and AquaCrop models.

in NHP region using the University of Nebraska CropWatch variety trial data from Clay, Lincoln and Phelps counties during the years 2009-2015. The calibrated models were used to simulate maize yield based on long-term historic weather data (19882015). The simulated yields were then compared with observed NASS yields.

The study demonstrated that the calibration performance of both DSSAT and AquaCrop models was, in general, representative of the observations for the three cultivars calibrated at all the three locations. The results indicated that both the models studied have the capability of simulating maize yields at a regional scale in absence of detailed in-season growth data for calibration. The differences that exist between the performance of the two models, despite using the exactly same crop management, weather and other input data, could be attributed to the fact that both the models are structured differently. For all the locations studied the median simulated maize yield of AquaCrop was higher than that of DSSAT and both the models overestimated yield as compared to observed county averages. Overall, both the models were able to simulate maize yield reasonably well as compared to observed yields both during calibration as well as historic time series.

Description of agricultural systems and their performance through system analysis and understanding the natural processes behind them is the core principle behind crop models and their use as decision support tools. As stated earlier, the calibration of these crop growth and agricultural systems models requires an integrated research approach between setting up field experiments and recording intensive in season 
crop development data. This method presented in our study of using multienvironment crop variety trial data to estimate the cultivar coefficients of crop is a good alternative when detailed crop growth data from during the season are not available. Availability of breeder/variety trial datasets from different locations and over a range of crop management scenarios like planting dates when combined with a systematic approach can prove helpful in calibrating and using crop models in data scarce environments (Adnan et al. 2019). We found that a large number (multiple years and multiple locations) of variety trials that have only end of season yield data can be successfully used to derive cultivar information to use in two different crop models. Although the long-term simulations indicated some uncertainty in the model behaviors, use of two different crop models that have different descriptions for various crop growth and other physical processes could be useful in generating more reliable results than using averages. The results also highlighted that there is a necessity for adjusting model parameters for regional conditions. This need could be discounted when using data from locations with different climatic conditions within a region (Klein et al. 2012) (e.g., variety trials).

As we move toward advanced application of crop models to study impacts of changing climate and improved hybrids, among others; use of multimethod and multimodel ensembles will improve the risk assessment and forecasts of crop production (Liu et al. 2016). While not always better, this approach of using multimodels when detailed, in season crop growth data are not available, could have a wide variety of applications in both research and policy. Obtaining end-of-season yield estimates at the field scale over a region from inexpensive sources (e.g., field variety trials conducted by Land-grant institutions) could improve the ability to conduct evaluations of various management interventions on our agricultural production systems. Other applications of this approach could be in studying and understanding yield gaps and their sources in absence of extensive crop management data (Burke and Lobell 2017).

As discussed earlier, crop models have been extensively utilized in yield impact studies under various circumstances and environment. With integration of various models (Haacker et al. 2019) becoming more common, crop models can also play a significant role in studying the overall sustainability of water resources for crop production. Several recent studies have utilized DSSAT, AquaCrop and other crop simulation models to optimize the use of groundwater for irrigation in the Ogallala Aquifer Region and NHP (Rad et al. 2020; Xiang et al. 2020). Sustainability studies of water resources in a changing environment have also used crop models (Araya et al. 2017a, b, c;
Sharda et al. 2019) to understand the impact on crop yields under different irrigation strategies.

It is important to note that although the results of this study showed that variety trials data can be a valuable for crop model calibration for areas where detailed in-season crop growth data from field experiments are not available, calibration of crop models based on end of season yield is not a replacement of calibration procedure when more elaborate data are present.

\section{ACKNOWLEDGMENTS}

The development of this publication was supported by the National Institute of Food and Agriculture, U.S. Department of Agriculture, award number 2016-68007-25066, "Sustaining agriculture through adaptive management to preserve the Ogallala aquifer under a changing climate." Statements from the authors do not represent official positions of USDA-NIFA.

\section{AUTHORS' CONTRIBUTIONS}

Vaishali Sharda: Conceptualization; data curation; formal analysis; investigation; methodology; software; validation; visualization; writing-original draft; writing-review \& editing. Mesfin M. Mekonnen: Data curation; formal analysis; investigation; methodology; software; validation; writing-original draft; writing-review \& editing. Chittaranjan Ray: Funding acquisition; project administration; resources; supervision; writing-review \& editing. Prasanna H. Gowda: Funding acquisition; project administration; resources; supervision; writing-review \& editing.

\section{LITERATURE CITED}

Abedinpour, M., A. Sarangi, T.B.S. Rajput, M. Singh, H. Pathak, and T. Ahmad. 2012. "Performance Evaluation of AquaCrop Model for Maize Crop in a Semi-Arid Environment." Agricultural Water Management 110: 55-66. https://doi.org/10.1016/j.a gwat.2012.04.001.

Adnan, A.A., J. Diels, J.M. Jibrin, A.Y. Kamara, P. Craufurd, A.S. Sahibu, I.B. Mohammed, and Z.E.H. Tonnang. 2019. "Options for Calibrating CERES-Maize Genotype Specific Parameters under Data-Scarce Environments." PLoS One 14 (2): e0200118. https://doi.org/10.1371/journal.pone.0200118.

Alexandrov, V.A., and G. Hoogenboom. 2000. "Vulnerability and Adaptation Assessments of Agricultural Crops under Climate Change in the Southeastren USA." Theoretical and Applied Climatology 67: 45-63. https://doi.org/10.1007/s007040070015.

Allen, R.G., L.S. Pereira, D. Raes, and M. Smith. 1998. Crop Evapotranspiration - Guidelines for Computing Crop Water Requirements - FAO Irrigation and Drainage Paper 56. Rome: FAO-Food and Agriculture Organization of the United Nations.

Anothai, J., A. Patanothai, S. Jogloy, K. Pannangpetch, K.J. Boote, and G. Hoogenboom. 2008. "A Sequential Approach for 
Determining the Cultivar Coefficients of Peanut Lines Using End-of-Season Data of Crop Performance Trials." Field Crops Research 108: 169-78. https://doi.org/10.1016/j.fcr.2008.04.012.

Araya, A., S. Habtu, K.M. Hadgu, A. Kebede, and T. Dejene. 2010a. "Test of AquaCrop Model in Simulating Biomass and Yield of Water Deficient and Irrigated Barley (Hordeum vulgare)." Agricultural Water Management 97: 1838-46. https://doi. org/10.1016/j.agwat.2010.06.021.

Araya, A., S.D. Keesstra, and L. Stroosnijder. 2010b. "Simulating Yield Response to Water of Teff (Eragrostis tef) with FAO's AquaCrop Model." Field Crops Research 116: 196-204. https://d oi.org/10.1016/j.fcr.2009.12.010.

Araya, A., I. Kisekka, P.H. Gowda, and P.V. Vara Prasad 2017a. "Evaluation of Waterlimited Cropping Systems in a Semiarid Climate Using DSSAT-CSM." Agricultural Systems 150: 86-98. https://doi.org/10.1016/j.agsy.2016.10.007.

Araya, A., I. Kisekka, X. Lin, P.V. Vara Prasad, P.H. Gowda, C. Rice, and A. Andales. 2017b. "Evaluating the Impact of Future Climate Change on Irrigated Maize Production in Kansas." Climate Risk Management 17: 139-54. https://doi.org/10.1016/j.crm. 2017.08.001.

Araya, A., I. Kisekka, P.V. Vara Prasad, and P.H. Gowda. 2017c. "Evaluating Optimum Limited Irrigation Management Strategies for Corn Production in the Ogallala Aquifer Region." Journal of Irrigation and Drainage Engineering 143 (10): 04017041. https://doi.org/10.1061/(ASCE)IR.1943-4774.0001228.

Araya, A., and L. Stroosnijder. 2010. "Effects of Tied Ridges and Mulch on Barley (Hordeum vulgare) Rainwater Use Efficiency and Production in Northern Ethiopia." Agricultural Water Management 97: 841-47. https://doi.org/10.1016/j.agwat.2010.01. 012.

Asseng, S., F. Ewert, C. Rosenzweig, J.W. Jones, J.L. Hatfield, A.C. Ruane, K.J. Boote et al. 2013. "Uncertainty in Simulating Wheat Yields under Climate Change." Nature Climate Change 3: 827-32. https://doi.org/10.1038/nclimate1916

AWDN. 2018. Automated Weather Data Network. https://hprcc. unl.edu/awdn.php.

Bannayan, M., N. Crout, and G. Hoogenboom. 2003. "Application of the CERES-Wheat Model for Within-Season Prediction of Winter Wheat Yield in the United Kingdom." Agronomy Journal 95: 114-25. https://doi.org/10.2134/agronj2003.0114.

Bao, Y., G. Hoogenboom, R. McClendon, and G. Vellidis. 2017. "A Comparison of the Performance of the CSM-CERES-Maize and EPIC Models Using Maize Variety Trial Data.” Agricultural Systems 150: 109-19. https://doi.org/10.1016/j.agsy.2016.10.006.

Basak, J.K., M.A. Ali, M.N. Islam, and M.A. Rashid. 2010. "Assessment of the Effect of Climate Change on Boro Rice Production in Bangladesh Using DSSAT Model.” Journal of Civil Engineering (IEB) 38 (2): 95-108.

Basso, B., J.T. Ritchie, P.R. Grace, and L. Sartori. 2006. "Simulation of Tillage Systems Impact on Soil Biophysical Properties Using the SALUS Model.” Italian Journal of Agronomy 4: 67788. https://doi.org/10.4081/ija.2006.677.

Bassu, S., N. Brisson, J. Durand, K.J. Boote, J. Lizaso, J.W. Jones, C. Rosenzweig et al. 2014. "How Do Various Maize Crop Models Vary in Their Responses to Climate Change FACTORS?" Global Change Biology 20: 2301-20. https://doi.org/10.1111/gcb.12520

Brilli, L., L. Bechini, M. Bindi, M. Carozzi, D. Cavalli, R. Conant, C.D. Dorich et al. 2017. "Review and Analysis of Strengths and Weaknesses of Agro-Ecosystem Models for Simulating C and N Fluxes." Science of the Total Environment 598: 445-70. https://d oi.org/10.1016/j.scitotenv.2017.03.208.

Burke, M., and D.B. Lobell. 2017. "Satellite-Based Assessment of Yield Variation and Its Determinants in Smallholder African Systems." Proceedings of the National Academy of Sciences of the United States of America 114 (9): 2189-94. https://doi.org/10. 1073/pnas.1616919114.
Carbone, G., L. Mearns, T. Mavromatis, E. Sadler, and D. Stoksbury. 2003. "Evaluating CROPGRO-Soybean Performance for Use in Climate Impact Studies." Agronomy Journal 95: 537-44. https://doi.org/10.2134/agronj2003.0537.

Challinor, A.J., C. Müller, A. Senthold, C. Deva, K.J. Nicklin, E. Vanuytrecht, S. Whitfield, J. Ramirez-Villegas, and A.-K. Koehler. 2018. "Improving the Use of Crop Models for Risk Assessment and Climate Change Adaptation." Agricultural Systems 159: 296-306. https://doi.org/10.1016/j.agsy.2017.07.010.

Dias, M.P., C.M. Navaratne, K.D. Weerasinghe, and R.H. Hettiarachchi. 2016. "Application of DSSAT Crop Simulation Model to Identify the Changes of Rice Growth and Yield in Nilwala River Basin for Mid-centuries under Changing Climatic Conditions." Procedia Food Science 6: 159-63. https://doi.org/10.1016/j. profoo.2016.02.039.

Doorenbos, J., and A.H. Kassam. 1979. "Yield Response to Water." FAO Drainage and Irrigation Paper. Rome, Italy: Food and Agriculture Organization.

Edgerton, M.D. 2009. "Increasing Crop Productivity to Meet Global Need for Feed, Food and Fuel." Plant Physiology 149 (1): 7-13.

Gaiser, T., I.D. Barros, F. Sereke, and F.M. Lange. 2010. "Validation and Reliability of the EPIC Model to Simulate Maize Production in Small-Holder Farming Systems in Tropical Subhumid West Africa and Semi-arid Brazil." Agriculture, Ecosystems \& Environment 135: 318-27.

Garibay, V.M., K. Kothari, S. Ale, III, D.C. Gitz, G.D. Morgan, and C.L. Munster. 2019. "Determining Water-Use-Efficient Irrigation Strategies for Cotton Using the DSSAT CSM CROPGROCotton Model Evaluated With in-Season Data." Agricultural Water Management 223: 105695. https://doi.org/10.1016/j.agwat. 2019.105695

Grassini, P., L.G.J. van Bussel, J. Van Wart, J. Wolf, L. Claessens, H. Yang, H. Boogaard, H. de Groot, M.K. van Ittersum, and K.G. Cassman. 2015. "How Good is Good Enough? Data Requirements for Reliable Crop Yield Simulations and YieldGap Analysis." Field Crops Research 177: 49-63. https://doi.org/ 10.1016/j.fcr.2015.03.004.

Grassini, P., J.E. Spect, M. Tollenaar, I. Ciampitti, and K.G. Cassman. 2015. "Chapter 2 - High-Yield Maize-Soybean Cropping Systems in the US Corn Belt." In Crop Physiology (Second Edition) - Applications for Genetic Improvement and Agronomy, edited by V.C. Sadras and D.F. Calderini, 17-41. Academic Press. https://doi.org/10.1016/B978-0-12-417104-6.00002-9.

Greaves, G., and Y.-M. Wang. 2016. "Assessment of FAO AquaCrop Model for Simulating Maize Growth and Productivity under Deficit Irrigation in a Tropical Environment." Water 8: 557. https://doi.org/10.3390/w8120557.

Guerra, L.C., G. Hoogenboom, A. Garcia y Garcia, P. Banterng, and J.P. Beasely. 2008. "Determination of Cultivar Coefficients for the CSM-CROPGRO-Peanut Model Using Variety Trial Data." Transactions of the American Society of Agricultural and Biological Engineers 54: 1471-81. https://doi.org/10.13031/2013. 25227.

Gupta, H.V., M.P. Clark, J.A. Vrugt, G. Abramowitz, and M. Ye. 2012. "Towards a Comprehensive Assessment of Model Structural Adequacy.” Water Resources Research 48. https://doi.org/ 10.1029/2011WR011044

Haacker, E.M.K., V. Sharda, A.M. Cano, R.A. Hrozencik, A. Núñez, Z. Zambreski, S. Nozari et al. 2019. "Transition Pathways to Sustainable Agricultural Water Management: A Review of Integrated Modeling Approaches." Journal of the American Water Resources Association 55: 6-23. https://doi.org/10.1111/17521688.12722 .

Heng, L.K., T. Hsia, S. Evett, T. Howell, and P. Steduto. 2009. "Validating the FAO AquaCrop Model for Irrigated and Water Deficient Corn.” Agronomy Journal 101 (3): 488-98. https://doi. org/10.2134/agronj2008.0029xs. 
Hermans, C., I.R. Geijzendorffer, F. Ewert, M.J. Metzger, P.H. Vereijken, G.B. Woltjer, and A. Verhagen. 2010. "Exploring the Future of European Crop Production in a Liberalised Market, with Specific Consideration of Climate Change and the Regional Competitiveness." Ecological Modelling 221: 2177-87. https://d oi.org/10.1016/j.ecolmodel.2010.03.021.

Holzworth, D.P., V. Snow, S. Janssen, I.N. Athanasiadis, M. Donatelli, G. Hoogenboom, J.W. White, and P. Thorburn. 2015. "Agricultural Production Systems Modelling and Software: Current Status and Future Prospects." Environmental Modelling \& Software 72 (1): 276-86. https://doi.org/10.1016/j.envsoft.2014.12. 013.

Hoogenboom, G. 2000. "Contribution of Agrometeorology to the Simulation of Crop Production and Its Application." Agricultural and Forest Meteorology 103: 137-57. https://doi.org/10.1016/ S0168-1923(00)00108-8.

Hoogenboom, G., J.W. Jones, P.W. Wilkens, C.H. Porter, W.D. Batchelor, L.A. Hunt, K.J. Boote et al. 2015. "Decision Support System for Agrotechnology Transfer (DSSAT) Version 4.6." Prosser, WA. http://dssat.net.

Hsiao, T.C., L. Heng, P. Steduto, B. Rojas-Lara, D. Raes, and E. Fereres. 2009. "AquaCrop - The FAO Crop Model to Simulate Yield Response to Water: III. Parameterization and Testing for Maize." Agronomy Journal 101: 448-59.

Huang, X., G. Huang, C. Yu, S. Ni, and L. Yu. 2017. "A Multiple Crop Model Ensemble for Improving Broad-Scale Yield Prediction Using Bayesian Model Averaging." Field Crops Research 211: 114-24. https://doi.org/10.2134/agronj2008.0218s.

Hunt, L.A., S. Pararajasingham, J.W. Jones, G. Hoogenboom, D.T. Imamura, and R.M. Ogoshi. 1993. "GENCALC: Software to Facilitate the Use of Crop Models for Analyzing Field Experiments." Agronomy journal 85: 1090-1094.

Iocola, I., S. Bassu, R. Farina, D. Antichi, B. Basso, M. Bindi, A.D. Marta et al. 2017. "Can Conservation Tillage Mitigate Climate Change Impacts in Mediterranean Cereal Systems? A Soil Organic Carbon Assessment Using Long Term Experiments." European Journal of Agronomy 90: 96-107. https://doi.org/10. 1016/j.eja.2017.07.011.

Jones, J.W., G. Hoogenboom, C.H. Porter, K.J. Boote, W.D. Batchelor, L.A. Hunt, P.W. Wilkens, U. Singh, A.J. Gijsman, and J.T. Ritchie. 2003. "The DSSAT Cropping System Model." European Journal of Agronomy 18 (3): 235-65.

Keating, B.A., P.S. Carberry, G.I. Hammer, M.E. Probert, M.J. Robertson, D. Holzworth, N.I. Huth et al. 2003. "An Overview of APSIM, a Model Designed for Farming Systems Simulation." European Journal of Agronomy 18: 267-88. https://doi.org/10. 1016/S1161-0301(02)00108-9.

Kisekka, I., J.P. Aguilar, D.H. Rogers, J. Holman, D.M. O'Brein, and N. Klocke. 2016. "Assessing Deficit Irrigation Strategies for Corn Using Simulation." Transactions of the American Society of Agricultural and Biological Engineers 59 (1): 303-17. https://doi.org/10.13031/trans.59.11206.

Klein, T., P. Calanca, A. Holzkamper, N. Lehmann, A. Roesch, and J. Fuhrer. 2012. "Using Farm Accountancy Data to Calibrate a Crop Model for Climate Impact Studies." Agricultural Systems 111: 23-33.

Liu, B., S. Asseng, C. Müller, F. Ewert, J. Elliott, D. Lobell, P. Martre et al. 2016. "Similar Estimates of Temperature Impacts on Global Wheat Yield by Three Independent Methods." Nature Climate Change 6: 1130-37. https://doi.org/10.1038/nclimate 3115.

Liu, H., J. Yang, C. Tan, C. Drury, W. Reynolds, T.Q. Zhang, Y.L. Bai, J. Jin, P. He, and G. Hoogenboom. 2011. "Simulating Water Content, Crop Yield and Nitrate-N Loss Under Free and Controlled Tile Drainage with Subsurface Irrigation Using the DSSAT Model." Agricultural Water Management 98 (6): 110511. https://doi.org/10.1016/j.agwat.2011.01.017.
Liu, X., J. Andersen, H. Yang, and D. Niyogi. 2015. "Calibration and Validation of Hybrid-Maize Crop Model for Regional and Application over the U.S. Corn Belt." Earth Interactions 19: 116. https://doi.org/10.1175/EI-D-15-0005.1.

Martre, P., D. Wallach, S. Asseng, F. Ewert, J.W. Jones, R.P. Rötter, K.J. Boote et al. 2015. "Multimodel Ensembles of Wheat Growth: Many Models are Better Than One." Global Change Biology 21: 911-25.

McNider, R.T., C.H. Handyside, K. Doty, W.L. Ellenburg, J.F. Cruise, J.R. Christy, D. Moss, V. Sharda, G. Hoogenboom, and P. Caldwell. 2015. "An Integrated Crop and Hydrologic Modeling System to Estimate Hydrologic Impacts of Crop Irrigation Demands." Environmental Modelling \& Software 72: 341-55. https://doi.org/10.1016/j.envsoft.2014.10.009.

NCSS. 2013. "NCSS Soil Characteristics Database." http://ncss labdatamart.ne.egov.usda.gov.

Nelson, G., M.W. Rosegrant, A. Palazzo, I. Gray, C. Ingersoll, R. Robertson, S. Tokgoz et al. 2010. Food Security, Farming and Climate Change to 2050. Washington: IFPRI.

Nelson, G.C., H. Valin, R.D. Sands, P. Havlík, H. Ahammad, D. Deryng, J. Elliott et al. 2014. "Climate Change Effects on Agriculture: Economic Response to Biophysical Shocks." Proceedings of the National Academy of Sciences of the United States of America 111 (9): 3274-79. https://doi.org/10.1073/pnas. 1222465110.

Qian, J., and Z. Zhao. 2017. "Estimating the Contribution of New Seed Cultivars to Increase n Crop Yields: A Case Study for Corn.” Sustainability 9 (1282): 1-11. https://doi.org/10. 3390/su9071282.

Raes, D., P. Steduto, T.C. Hsiao, and E. Fereres. 2009. "AquaCropThe FAO Crop Model to Simulate Yield Response to Water: II. Main Algorithms and Software Description." Agronomy Journal 101: 438-47. https://doi.org/10.2134/agronj2008.0140s.

Rao, D. 2002. "Validation of Corn, Soybean, and Wheat Models in DSSAT for Assessing Climate Change Impacts on Midwest Crop Production." In Effects of Climate Change and Variability on Agricultural Production Systems, edited by O.C. Doering, J.C. Randolph, J. Southworth, and R.A. Pfeifer, 101-125. Boston: Springer.

Regassa, T.H., R.N. Klein, B. Anderson, C. Shapiro, and J. Krall. 2009. Spring Seed Guide 2010. Nebraska Variety and Hybrid Tests, Extension Circular 101. Lincoln, NE: UNL Institute of Agriculture and Natural Resources, University of Nebraska.

Regassa, T.H., G.R. Kruger, S.Z. Knezevic, C.A. Shapiro, and B. Anderson. 2010. Spring Seed Guide 2011. Nebraska Variety and Hybrid Tests, Extension Circular 101. Lincoln, NE: UNL Institute of Agriculture and Natural Resources, University of Nebraska.

Regassa, T.H., G.R. Kruger, S.Z. Knezevic, C.A. Shapiro, B. Anderson, and D. Santra. 2012. Spring Seed Guide 2013. Nebraska Variety and Hybrid Tests, Extension Circular 101. Lincoln, NE: UNL Institute of Agriculture and Natural Resources, University of Nebraska.

Regassa, T.H., G.R. Kruger, S.Z. Knezevic, C.A. Shapiro, B. Anderson, D.K. Santra, and J. Krall. 2011. Spring Seed Guide 2012. Nebraska Variety and Hybrid Tests, Extension Circular 101. Lincoln, NE: UNL Institute of Agriculture and Natural Resources, University of Nebraska.

Regassa, T.H., D. Santra, C.A. Shapiro, G.R. Kruger, and B. Anderson. 2013. Spring Seed Guide 2014. Nebraska Variety and Hybrid Tests, Extension Circular 101. Lincoln, NE: UNL Institute of Agriculture and Natural Resources, University of Nebraska.

Regassa, T.H., and C.A. Shapiro. 2014. Spring Seed Guide 2015. Nebraska Variety and Hybrid Tests, Extension Circular 101. Lincoln, NE: UNL Institute of Agriculture and Natural Resources, University of Nebraska. 
Regassa, T.H., and C.A. Shapiro. 2015. Spring Seed Guide 2016. Nebraska Variety and Hybrid Tests, Extension Circular 101. Lincoln, NE: UNL Institute of Agriculture and Natural Resources, University of Nebraska.

Richards, R.A. 2006. "Physiological Traits Used in the Breeding of New Cultivars for Water-Scarce Environments." Agricultural Water Management 80 (1-3): 197-211. https://doi.org/10.1016/j.a gwat.2005.07.013.

Ritchie, J.T., U. Singh, D.C. Godwin, and W.T. Bowen. 1998. "Cereal Growth, Development, and Yield." In Understanding Options for Agricultural Production (Volume 7), edited by G.Y. Tsuji, G. Hoogenboom, and P.K. Thorton, 79-98. Dordrecht. The Netherlands: Springer.

Rosenzweig, C., and A. Iglesias. 1998. "The Use of Crop Models for International Climate Change Impact Assessment." In Understanding Options for Agricultural Production. Systems Approaches for Sustainable Agricultural Development, edited by G.Y. Tsuji, G. Hoogenboom, and P.K. Thorton, 267-92. Dordrecht: Springer.

Rosenzweig, C., J.W. Jones, J.L. Hatfield, A.C. Ruane, K.J. Boote, P. Thorburn, J.M. Antle et al. 2013. "The Agricultural Model Intercomparison and Improvement Project (AgMIP): Protocols and Pilot Studies." Agricultural and Forest Meteorology 170: 166-82. https://doi.org/10.1016/j.agrformet.2012.09.011.

Rötter, R., T. Palosuo, K. Kersebaum, C. Angulo, M. Bindi, F. Ewert, R. Ferrise et al. 2012. "Simulation of Spring Barley Yield in Different Climatic Zones of Northern and Central Europe: A Comparison of Nine Crop Models." Field Crops Research 133: 23-36. https://doi.org/10.1016/j.fcr.2012.03.016.

Rouhi Rad, M., E.M.K. Haacker, V. Sharda, S. Nozari, Z. Xiang, A. Araya, V. Uddameri, J.F. Suter, and P. Gowda. 2020. "MOD\$\$AT: A Hydro-Economic Modeling Framework for Aquifer Management in Irrigated Agricultural Regions." Agricultural Water Management 238: 106194. https://doi.org/10.1016/j.agwat.2020.106194.

Saseendran, S.A., D.C. Nielsen, L.R. Ahuja, L. Ma, and D.J. Lyon. 2013. "Simulated Yield and Profitability of Five Potential CRPS for Intensifying the Dryland Wheat-Fallow Production System." Agricultural Water Management 116: 175-92. https://doi.org/10. 1016/j.agwat.2012.07.009.

Semenov, M., and P.R. Shewry. 2011. "Modelling Predicts That Heat Stress, Not Drought, Will Increase Vulnerability of Wheat in Europe." Scientific Reports 1: 66. https://doi.org/10.1038/sre p00066.

Sharda, V., P.H. Gowda, G. Marek, I. Kisekka, C. Ray, and P. Adhikari. 2019. "Simulating the Impacts of Irrigation Levels on Soybean Production in Texas High Plains to Manage Diminishing Groundwater Levels." Journal of the American Water Resources Association 55 (1): 56-69. https://doi.org/10.1111/17521688.12720 .

Sharda, V., C. Handyside, B. Chaves, R.T. McNider, and G. Hoogenboom. 2017. "The Impact of Spatial Soil Variability on Simulation of Regional Maize Yield." Transactions of the American Society of Agricultural and Biological Engineers 60 (6): 2137-48. https://doi.org/10.13031/trans.12374.

Smith, A., B. Cullis, and A. Gilmour. 2001. "The Analysis of Crop Variety Evaluation Data in Australia." Australian \& New Zealand Journal of Statistics 43 (2): 129-45. https://doi.org/10.1111/ 1467-842X.00163.

Smith, A.B., B.R. Cullis, and R. Thompson. 2005. "The Analysis of Crop Cultivar Breeding and Evaluation Trials: An Overview of Current Mixed Model Approaches." The Journal of Agricultural Science 143: 449-62. https://doi.org/10.1017/S0021859605005587.

Soler, C., V. Bado, K. Traore, B. McNair, J.W. Jones, and G. Hoogenboom. 2011. "Soil Organic Carbon Dynamics and Crop Yield for Different Crop Rotations in a Degraded Ferruginous Tropical Soil in a Semi-arid Region: A Simulation Approach.”
Journal of Agricultural Science 149: 579-93. https://doi.org/10. 1017/S0021859611000050.

Soler, C.M., P.C. Sentelhas, and G. Hoogenboom. 2007. "Application of the CSM-CERES-Maize Model for Planting Date Evaluation and Yield Forecasting for Maize Grown Off-Season in a Subtropical Environment." European Journal of Agronomy 27 (2-4): 165-77. https://doi.org/10.1016/j.eja.2007.03.002.

Steduto, P., T.C. Hsiao, E. Fereres, and D. Raes. 2012. "Crop Yield Response to Water." FAO Irrigation and Drainage Paper Nr. 66. Food and Agriculture Organization (FAO), Rome, Italy.

Steduto, P., T.C. Hsiao, D. Raes, and E. Fereres. 2009. "AquaCrop - The FAO Crop Model to Simulate Yield Response to Water: I. Concepts and Underlying Principles." Agronomy Journal 101: 426-37. https://doi.org/10.2134/agronj2008.0139s.

Stricevic, R., M. Cosic, N. Djurovic, B. Pejic, and L. Maksimovic. 2011. "Assessment of the FAO AquaCrop Model in the Simulation of Rainfed and Supplementally Irrigated Maize, Sugar Beet and Sunflower." Agricultural Water Management 98: 1615-21. https://doi.org/10.1016/j.agwat.2011.05.011.

Suleiman, A.A., and J.T. Ritchie. 2003. "Modeling Soil Water Redistribution during Second-Stage Evaporation.” Soil Science Society of America Journal 67 (2): 377-86. https://doi.org/10.2136/sssa j2003.0377.

Thorp, K.R., K.C. DeJonge, A.L. Kaleita, W.D. Batchelor, and J.O. Paz. 2008. "Methodology for the Use of DSSAT Models for Precision Agriculture Decision Support." Computers and Electronics in Agriculture 64 (2): 276-85. https://doi.org/10.1016/j.compag. 2008.05.022.

Todorovic, M., R. Albrizio, L. Zivotic, M.T.A. Saab, C. Stöckle, and P. Steduto. 2009. "Assessment of AquaCrop, CropSyst, and WOFOST Models in the Simulation of Sunflower Growth under Different Water Regimes." Agronomy Journal 101: 509-21. https://doi.org/10.2134/agronj2008.0166s.

Tsuji, G.Y., G. Hogenboom, and P.K. Thorton. 1998. Understanding Options for Agricultural Production. Dordrecht, The Netherlands: Springer.

Tubiello, F., C. Rosenzweig, R. Goldberg, S. Jagtap, and J.W. Jones. 2002. "Effects of Climate Change on US Crop Production: Simulation Results Using Two Different GCM Scenarios. Part I: Wheat, Potato, Maize, and Citrus." Climate Research 20: 25970.

USDA NASS. 2018. "National Agricultural Statistics Services Quick Stats." https://quickstats.nass.usda.gov/.

Vanuytrecht, E., D. Raes, P. Steduto, T. Hsiao, E. Fereres, L.K. Heng, M. Garcia Vila, and P.M. Moreno. 2014. "AquaCrop: FAO's Crop Water Productivity and Yield Response Model." Environmental Modelling \& Software 62: 351-60. https://doi.org/ 10.1016/j.envsoft.2014.08.005.

Watson, J., and A. Challinor. 2013. "The Relative Importance of Rainfall, Temperature and Yiield Data for a Regional-Scale Crop Model." Agricultural and Forest Meteorology 170: 47-57. https://doi.org/10.1016/j.agrformet.2012.08.001.

Williams, J.R., C.A. Jones, J.R. Kiniry, and D.A. Spanel. 1989. "The EPIC Growth Model." Transactions of the American Society of Agricultural Engineers 32 (2): 497-511.

Willmott, C.J., S.M. Robesonb, and K. Matsuuraa. 2012. "Short Communication: A Refined Index of Model Performance." International Journal of Climatology 32 (13): 2088-94. https://doi. org/10.1002/joc.2419.

Xiang, Z., R.T. Bailey, S. Nozari, Z. Husain, I. Kisekka, V. Sharda, and P.H. Gowda. 2020. "DSSAT-MODFLOW: A New Modeling Framework for Exploring Groundwater Conservation Strategies in Irrigated Areas." Agricultural Water Management 232: 106033. https://doi.org/10.1016/j.agwat.2020.106033.

Yang, J.M., J. Yang, S. Liu, and G. Hoogenboom. 2014. "An Evaluation of the Statistical Methods for Testing the Performance of 
Crop Models with Observed Data." Agricultural Systems 127: $81-89$.

Yin, X., K.C. Kersebaum, C. Kollas, S. Baby, N. Beaudoin, K. Manevski, T. Palosuo et al. 2017. "Multi-Model Uncertainty Analysis in Predicting Grain N for Crop Rotations in Europe." European
Journal of Agronomy 84: 152-65. https://doi.org/10.1016/j.eja. 2016.12.009.

Zeleke, K.T., D. Luckett, and R. Cowley. 2011. "Calibration and Testing of the FAO AquaCrop Model for Canola." Agronomy Journal 103: 1610-18. 